\title{
Methodology for assessing humanitarian funding flows to local and national actors
}

\section{CHRISTIAN ELS}

Consultant

Aggregated data on direct funding flows to local humanitarian actors exists at the global level, but there is limited aggregated knowledge of how much funding - and through what channels - goes to local actors at the country level, particularly funding that reaches local actors indirectly. Deeper analysis at the country level can provide useful information for all humanitarian actors to make practical changes in the financing architecture and better meet commitments made through the Grand Bargain and other international agreements, like the Charter4Change. The methodology described here is used to guide research on assessing humanitarian funding to local and national actors in Uganda and Bangladesh. It has been developed and is published now to support other aid agencies in similar analysis in other contexts. 


\section{ACRONYMS}

\begin{tabular}{ll} 
CBPF & Country-Based Pooled Fund \\
CERF & Central Emergency Respond Fund \\
CRS & Creditor Reporting System \\
CSO & Civil society organization \\
DAC & Development Assistance Committee \\
DFID & Department for International Development (UK) \\
DI & Development Initiatives \\
ECHO & Directorate-General for European Civil Protection and Humanitarian Aid \\
ELNHA & Operations \\
FTS & Empowering local and national humanitarian actors \\
HQ & Financial Tracking Service \\
ICRC & Headquarters \\
IFRC & International Committee of the Red Cross \\
INGO & International Federation of the Red Cross and Red Crescent Societies \\
LNHA & International non-government organization \\
NGO & Local and national humanitarian actors \\
OCHA & Non-government organization \\
OECD & United Nations Office for the Coordination of Humanitarian Affairs \\
OFDA & Organisation for Economic Co-operation and Development \\
ONS & Office of US Foreign Disaster Assistance \\
PNS & Operation National Red Cross/Crescent Society \\
RCRC & Participating National Red Cross/Crescent Society \\
WFP & ICRC+IFRC+PNS \\
& World Food Programme \\
\hline
\end{tabular}


In 2015, a series of consultations started under the High-Level Panel for Humanitarian Financing to decide on a road map to achieve a so-called 'Grand Bargain on efficiency' between the big donors and the main humanitarian organizations to improve the effectiveness and efficiency of humanitarian action. The resulting Grand Bargain Agreement, ${ }^{1}$ signed by 22 donors and 28 aid organizations and alliances committed to: 'Achieve by 2020 a global, aggregated target of at least 25 percent of humanitarian funding to local and national responders as directly as possible to improve outcomes for affected people and reduce transactional costs.' The outcome of this commitment aims to address the existing gaps and limits to funding local and national actors, thereby increasing and improving the very necessary humanitarian resources at the most local levels.

While aggregated data on direct funding flows to local actors exists at the global level, there is limited aggregated knowledge of how much funding - and through what channels - reaches local actors at the national level, particularly funding that reaches local actors indirectly. Deeper analysis at the national level can provide useful information for all humanitarian actors to make practical changes in the financing architecture and to better meet commitments made through the Grand Bargain and other international agreements. ${ }^{2}$ This methodology is being used to guide research on assessing humanitarian funding to local and national actors in Uganda and Bangladesh. It was also developed to support other aid agencies in similar analysis in other contexts.

Uganda and Bangladesh were selected as preliminary research studies as part of the Oxfam project Empowering Local and National Humanitarian Actors (ELNHA) program implementation plan. The ELNHA program runs on the principle of putting local and national humanitarian actors in the driver's seat to define their agenda and strategies and influence international humanitarian actors for their support. Among its priorities is to understand the funding modalities and amounts allocated from donors to local actors, to be able to define areas of influence and advocacy and make access to funding more available to local actors. The research will thus constitute a baseline for ELNHA programming, as well as provide evidence to promote the local humanitarian leadership agenda with international organizations at the national and global levels.

The humanitarian response across countries is vastly different in terms of incoming funding flows; for example, from $\$ 40 \mathrm{~m}$ per year in Bangladesh to more than $\$ 2 \mathrm{bn}$ in Syria; and in the type of humanitarian emergency (climate-related emergency, conflict, sudden onset, etc). Some countries deal with a humanitarian crisis within their borders, while others are involved with mainly refugee responses to crises in neighbouring countries. Given the diversity of humanitarian responses, this methodology will outline how research can be conducted in different settings, so comparable sets of data can be obtained.

The methodology is divided into several parts: in the first section, the research objectives and research questions are reviewed. An overall strategy is presented on how, and what kind of quantitative data should be collected to answer the research questions. It suggests collecting different types of data on three levels of specificity; Sections 2, 3 and 4 provide detailed descriptions on how to identify important data and how data can be accessed on these three different levels. 


\section{RESEARCH OBJECTIVES AND QUESTIONS}

The research questions and objectives can be divided into two categories: some have a strong quantitative focus with the necessity to collect hard financial data, while others focus more on qualitative aspects, for example, the partnership between international and national actors and examples of best practice. In this methodology, mainly quantitative questions will be of concern, as well as examples of qualitative questions asked in this study which can be adapted and edited based on local knowledge and an increasingly large literature and research on localization, partnership, etc.

The research questions and research objectives are as follows.

\section{Research objectives}

- To understand the amount of funding, both directly and indirectly, that reaches local and national humanitarian actors from specific international NGOs, UN agencies and members of the donor community in focus countries over the course of one financial year, and to quantify the amount of funding by expenditure area, to the extent possible (e.g. project, overheads, capacity development, etc.);

- To identify and analyze the different funding partnership modalities and mechanisms to local and national humanitarian actors in focus countries (e.g. available pooled funding modalities and national consortia managing donor funding, etc);

- To analyze the type of partnership in place between the donor and the local actors, as per the Principles of Partnership;

- To identify what have been the best practices and what are the barriers for donors to provide funding directly, and for local actors to access funding;

- To provide recommendations on how to create a funding space that involves local actors and promotes local ownership, efficiency and increased local capacity to manage funding for humanitarian assistance work.

\section{Research questions}

- How much donor funding is directly granted to local or national humanitarian actors? Based on what kind of partnership model? What is that funding spent on? If it is earmarked, on what?

- How much donor funding is indirectly granted to local or national humanitarian actors? Through what channels and based on what kind of partnership model? What is that funding spent on?

- To what extent do donors fund or track their humanitarian funding for women-led activities and women's rights organizations? Through what channels and based on what kind of partnership model? What is that funding spent on?

- What are the best practices for donors to provide funding directly? What are the barriers?

- What changes are needed nationally for local actors to access and manage greater and of better quality of direct and indirect funding?

The research questions and objectives lay out a research project that has not been undertaken yet, at such scale. Most existing similar studies have focused on a single donor (ECHO, ${ }^{3}$ OFDA, DFID), none of which are publicly available. Development Initiatives (DI) conducted traceability studies for single donor/pooled fund for the humanitarian response to floods in Sri Lanka in 2015 and the earthquake in Nepal (2015) which are publicly available. ${ }^{4}$ However, no such study has been 
conducted at a country level for multiple agencies and donors. Hence this methodology tries to find a balance between capturing the overall picture of funding flows to local and national humanitarian actors (LNHA) through various channels on a country level, and tracing individual transaction chains on a project level from international donors through INGOs and UN agencies to LNHAs. Data will therefore, be collected on three levels of specificity:

\section{Level 1}

\section{A, How much funding is channeled in various ways to LNHA?}

Data collection at this level aims to provide a comprehensive picture of the volume of funding reaching LNHAs within a given country. This will be done by capturing aggregated data on funding flows into and out of country-based donor government agencies, pooled funds, UN agencies and INGOs, by source; as well as the privately generated income of LNHAs, to the extent shared. The guiding principle will be to identify how much of the funding from these organizations reaches L/NHAs. While data collected will be as detailed as possible, it cannot be expected that all the surveyed organizations will be able to provide in-depth data including breakdowns of funding flows on a project level. The depth of the information mainly sourced on this level is limited to aggregated national-level data to obtain the relevant information from as many actors as possible.

While it is anticipated that this approach will capture the majority of funding that ultimately reaches LNHAs - as funding rarely passes between international actors once it reaches an INGO operating in a country - it will not capture all of it and it will not enable us to identify funding flowing between LNHAs, such as funding from a national to a local NGO.

\section{B. How long is the transaction chain?}

In addition to providing as comprehensive as possible a picture on funding flows to LNHA on a national level, the length of the humanitarian transaction chain will be investigated: how many intermediaries are involved before goods, services and cash reach people affected by crises. So far, there is only anecdotal and small-scale evidence available on the length of the transaction chain and this study tries to answer this question on a country level, focusing on the largest UN agencies, INGOs and internationally operating members of the Red Cross and Red Crescent movement.. Once the dominant transaction chains are uncovered, a more detailed analysis will be conducted for some of them covering all direct and indirect cost components of the chain comprehensively. This is outlined in more detail in Level 3.

\section{How is the workload divided between international and national actors?}

Another important aspect at the country level is related to the division of the workload between international and national organizations. Donor reports and annual reports often indicate that INGOs and UN agencies implement projects together with their local and national partners, but rarely specify how the work is divided between local/national and international humanitarian actors. Since measuring the rates of implementation by the various parties involved is methodologically difficult in terms of how working hours were split for particular projects etc, it is suggested that data is collected on the number of full-time equivalent staff members (including volunteers) from international and local and national humanitarian actors. Such information can then be contrasted with the amount of funding received in order to answer questions along the line of: which type of organizations receive the most funding and which conduct most of the work. This kind of data can contribute to answering questions about the nature of the partnership between international and local and national actors.

While this question is not explicitly included in the pre-identified research questions, hard evidence on the relative size of the various types of organizations can support advocacy messages for a transformation of the humanitarian system. 
The detailed template for Level 1 data collection is outlined in Annex 1.

\section{Level 2}

The type of data collection and analysis for Level 2 can be carried out between the comprehensive picture on the overall country perspective that Level 1 data provides and Level 3, which looks at the totality of the costs of humanitarian response in its different stages.

Data collected for this level responds to questions on the quality of partnerships and the nature of the provided funding. The analysis will identify current challenges in the relationship between local and international actors, the access to funding and examples of best practice. Level 2 data (for example, on the amount of overheads paid, or funding provided for capacity building) will then serve to support the recommendations on how to overcome some of the challenges and provide hard evidence for some of best practice examples. It can include data reviewing the different practices of international actors to pay for adequate administrative support. The focus of the data collection should be very much informed by national actors. Data will be collected either from all of the organizations contacted for the Level 1 research or will focus on a particular subset of organizations.

\section{Level 3}

\section{How much of the funding reaches the people affected by crises?}

On the most fine-grained level, the study will provide case studies of funding flows for a small number of projects implemented by LNHAs. Based on information provided by national actors, funding will be tracked backwards through UN agencies and INGOs to government and private donors. The guiding principle for this part of the research will be a full-cost approach: not only costs that are outlined in project proposals and budgets will be included, but all relevant shares of costs at country office, regional office and international $\mathrm{HQ}$ office levels are estimated.

\section{YEAR OF FOCUS}

The financial year referred to in the research objective is the calendar year 2015. Given that many organizations have not issued their financial reports for 2016 at the time of writing, and internal financial reporting is still ongoing in early 2017 (including OECD Creditor Reporting System (CRS) data for 2016, which will be available only at the end of 2017), data from 2015 will be used for all the quantitative research. While some donors operate with financial years that are different from calendar years, this study will focus on the calendar year 2015, since most of the publicly available reporting uses calendar years. 


\section{DEFINITIONS}

The definitions of various local and national actors are as follows.

\begin{tabular}{|l|l|}
\hline Local and national actor & Definition \\
\hline National NGOs/CSOs & $\begin{array}{l}\text { NGOs and CSOs operating in the aid-recipient } \\
\text { country in which they are headquartered, } \\
\text { working in multiple sub-national regions, and } \\
\text { not affiliated to an international NGO. }\end{array}$ \\
\hline Local NGOs/CSOs & $\begin{array}{l}\text { NGOs/CSOs operating (either } \\
\text { formally/registered or informally/unregistered) } \\
\text { in a specific, geographically defined, sub- } \\
\text { national area of an aid-recipient country, } \\
\text { without affiliation to either a national or } \\
\text { international NGO/CSO. This grouping can } \\
\text { also include community-based organizations } \\
\text { and faith-based organizations. }\end{array}$ \\
\hline $\begin{array}{l}\text { Red Cross/Red Crescent } \\
\text { national societies }\end{array}$ & $\begin{array}{l}\text { National societies that are based in aid- } \\
\text { recipient countries. }\end{array}$ \\
\hline Local governments & $\begin{array}{l}\text { Local state actors in aid-recipient countries, } \\
\text { e.g. local/municipal authorities. }\end{array}$ \\
\hline National governments & $\begin{array}{l}\text { National authorities in aid-recipient countries, } \\
\text { e.g. national disaster management agencies } \\
\text { (NDMAs). }\end{array}$ \\
\hline
\end{tabular}

The research will be using these categories wherever possible. However, data by large UN agencies, country-based pooled funds (CBPF) and some INGOs indicates that national NGOs and local NGOs are often combined into one category. Therefore, the study will show some flexibility on whether a combined category of local and national NGOs will be used. Nonetheless, the above categories will be used as test categories against which the current categorization practice of international humanitarian actors (donors, INGOs and UN agencies) will be tested. A similar approach will be taken for national and local governments.

Donors, for purposes of this research, will be government, multilateral entities and private individuals and institutions only.

Direct funding is funding from donors which comes to LNHAs without intermediaries. Goods inkind are not counted in this assessment.

A set of categories of non-direct funding flows is proposed, based on the number of intermediaries. This is discussed in more detail in Section 1. For the final analysis and publication of the results, more simplified categories might be used, combining several non-direct funding flows into one category.

Funding flows are defined as cash grants; in-kind transfers are not funding flows, however, they are to be documented in a separate category whenever data is available. 


\section{LIMITATIONS, ASSUMPTIONS, AND RISK}

This methodology is based on several assumptions and its scope is limited. Further, the research outlined here entails risks, some of which are briefly discussed in this section.

The research methodology is not a research strategy: This methodology outlines the kind of quantitative and qualitative data that should be collected. However, it does not provide detailed advice and a step-by-step process for how this data should be collected. For example, for large humanitarian organizations it might be advisable to collect data at an $\mathrm{HQ}$ level; for others, the fastest approach is collecting data on a field or country office level. Before starting the research, strategies should be developed for collecting financial data in particular.

Funding to LNHA is only measured to the first LNHA recipient: Funding flows further from LNHA to another LNHA cannot be systemically documented with the quantitative approach outlined here (if data is collected only from international actors). However, qualitative research can be used to explore the relevance of implementing partners of LNHAs.

This research is not a traceability study: The research does not aim to trace specific funds through the system from donor, through intermediary agencies, to local/national actors. Using the pro-rata assumption, it instead provides detailed information on how money is distributed and flows through various humanitarian actors, not considering the individual identity and origin of the money.

Risk assessment: For assessing risks related to the successful outcome of the quantitative part of the study, i.e. obtaining the relevant financial data, at least two aspects have to be considered: risks associated with single actors in the transaction chain and risks related to the links between them. The methodology is designed to minimize link risks: the pro-rata assumption ensures that no detailed information is needed to know how money flows through the system of various humanitarian actors.

For assessing the single actor risk, the well-known formula which quantifies risk associated with an event as the probability of the event $(P)$ times expected loss/damage $(L)$ will be used: Risk $=P \times L$.

In the context of data collection, the term 'risk' refers to the successful outcome of the study being undermined by not obtaining data from a particular organization. The probability $\mathrm{P}$ refers to the likelihood of not obtaining data from an organization and the expected loss/damage $L$ is directly proportional to the size of the country program of the organization (the larger the country program, the more damaging are the effects on the outcome of the study if data are not obtained).

For simplicity, we will assume that the probability to obtain data is equal for all organizations. It follows that the risk related to not obtaining data and the successful outcome of the study is simply proportional to the size of the country program (since the probability $\mathrm{P}$ is a constant). The largest risk to the successful data collection of the study is entailed in not obtaining data from the largest UN agencies and INGOs. To reduce risks, it is important that larger organizations are strategically focused in the early stage of the study, so that data can be obtained by them. Before starting the research, a list of the country's largest humanitarian actors should be established.

Security concerns/sharing of data: Many organizations, especially in a protracted crisis context such as Uganda or sensitive conflicts such as Syria, might have security concerns with sharing data. Donors, in particular the US and UK, for example, do not publish the names of those INGOs to which they directly provide funding in the Syria response. Given these security concerns, it is important to collect data in these contexts in an aggregated and anonymized. Instead of asking for names of organizations, only data on an organization's type should be collected. All researchers and the Oxfam project team should ensure that participating organizations' security concerns are considered, based on transparent and reliable communication - necessary in all data collection. 


\section{LEVEL ONE}

\section{A. How much is channeled in various ways to LNHA?}

This methodology suggests mapping all major funding flows from donors through INGOs, UN and $R C R C$ to local and national actors. Such mapping of mainly financial flows responds to questions on the size of direct and indirect funding flows without being too constrained by a particular definition. In fact, funding flows to local and national actors can then easily be calculated based on various possible definitions of the terms 'local and national actors' and the terms 'direct and indirect funding'.

\section{Fig 1: The humanitarian 'transaction chain' and its main channels}

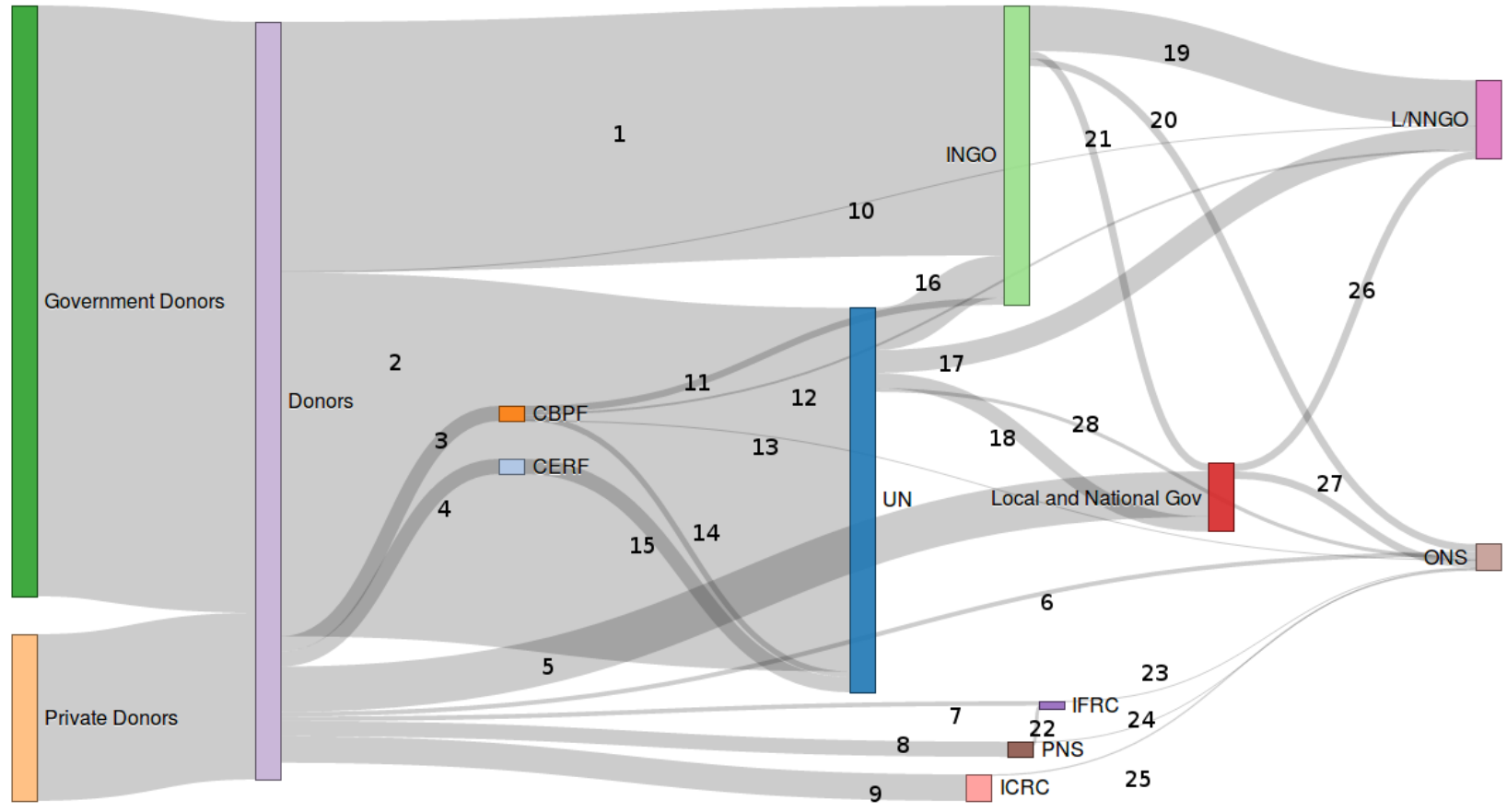

(c) Author (Christian Els), 2017.

Humanitarian funding flows through various channels from and to international and national humanitarian responders. In Figure 1, the flow diagram shows financial flows from donors through pooled funds/UN/INGOs/RCRC to local and national humanitarian actors. All relevant channels are included, though note that not all of them are relevant in every country and the sizes of the channels can vary. However, the UN-INGO-L/NNGO channel is likely to dominate in most settings. (ONS=Operational Red Cross/Crescent national society, PNS=Participating Red Cross/Crescent national society). For a discussion of the various channels and availability of data, see Table 1. 
Table 1: Main humanitarian funding channels and availability of data

\begin{tabular}{|c|c|c|c|c|}
\hline Channel & Origin & Recipient & Data & How to collect data? \\
\hline 1 & Donors & INGO & Incomplete & Amend FTS data with information from INGOs \\
\hline 2 & Donors & UN & Yes & Amend FTS data with information from UN \\
\hline 3 & Donors & CBPF & yes & CBPF website \\
\hline 4 & Donors & CERF & yes & CERF annual reports \\
\hline 5 & Donors & GOV & yes & Only DAC donors, available through OECD CRS \\
\hline 6 & Donors & ONS & incomplete & Amend FTS data with information from ONS \\
\hline 7 & Donors & IFRC & Incomplete & Amend FTS data with information from IFRC \\
\hline 8 & Donors & PNS & incomplete & Amend FTS data with information from PNS \\
\hline 9 & Donors & ICRC & Incomplete & Amend FTS data with information from IFRC \\
\hline 10 & Donors & L/NNGO & incomplete & $\begin{array}{l}\text { Amend FTS data with information from donor } \\
\text { gov, L/NNGO private funding data }\end{array}$ \\
\hline 11 & CBPF & INGO & yes & CBPF website \\
\hline 12 & CBPF & L/NNGO & yes & CBPF website \\
\hline 13 & CBPF & ONS & yes & CBPF website \\
\hline 14 & CBPF & UN & yes & CBPF website \\
\hline 15 & CERF & UN & yes & CERF annual reports \\
\hline 16 & UN & INGO & no & Source data from UN agencies \\
\hline 17 & UN & L/NNGO & no & Source data from UN agencies \\
\hline 18 & UN & GOV & no & Source data from UN agencies \\
\hline 19 & INGO & L/NNGO & no & Source data from INGOs \\
\hline 20 & INGO & ONS & no & Source data from INGOs \\
\hline 21 & INGO & GOV & no & Source data from INGOs \\
\hline 22 & PNS & IFRC & $?$ & $\begin{array}{l}\text { Source data form PNS/IFRC (IFRC annual } \\
\text { report: hum + dev data only) }\end{array}$ \\
\hline 23 & IFRC & ONS & no & Source data from IFRC and ONS, PNS \\
\hline 24 & PNS & ONS & no & Source data from PNS/ONS \\
\hline 25 & ICRC & ONS & yes & ICRC annual reports \\
\hline 26 & $\begin{array}{l}\text { Nat } \\
\text { Gov }\end{array}$ & L/NNGO & no & $\begin{array}{l}\text { Source data from national and local government } \\
\text { entities }\end{array}$ \\
\hline 27 & $\begin{array}{l}\text { Nat } \\
\text { Gov }\end{array}$ & ONS & no & $\begin{array}{l}\text { Source data from national and local government } \\
\text { entities }\end{array}$ \\
\hline
\end{tabular}

Source: Author (Christian Els), 2017. 


\section{Notes}

For the sake of this research, funding flows can be broadly divided in two types: flows where data is publicly available (mainly first-level funding flows and CBPF-related funding flows $-2-5,11-15$, 25) and flows without publicly available financial data.

Among the flows for which data is not publicly available, there are three types: direct channels $(6$, $10,26,27)$, and two indirect channels that involve UN agencies/INGOs $(1,2,16,17,18,19,21)$ and the RCRC movement $(7,8,9,20,22,2324,25)$ respectively.

\section{How to measure funding through various channels: non-public data sources}

For this study, not all of the channels are of equal importance and it is impossible to measure each individual funding flow within each channel on a country level. However, it is suggested to try to track at least part of the funding for all the 17 unknown channels. While this seems an arduous task, in fact the majority of these flows can be covered by data from 10-15 organizations.

For funding channels that involve international organizations, data will be sourced from the largest two to four international government donors, two to three UN agencies, four to seven INGOs and the ICRC, IFRC and one to two PNS. For determining the largest international actors, OCHA FTS data will be used. The research aims to cover at least 50 percent of the reported OCHA FTS funding for the respective country, which seems feasible using the suggested number of international organizations given that most of the humanitarian funding is provided to a few large UN agencies and major INGOs.

For private funding flows to L/NNGOs and the ONS, data will be sourced from a to-be-defined number of these organizations. Further, the national government entities in the affected country will be contacted to provide data on funding flows to L/NNGOs and the ONS.

\section{Main method of collecting data}

As outlined in the introduction, the country-level based research will focus on collecting data on aggregated funding flows only. For UN/INGOs/RCRC the data will focus on a country program level. Country programs are treated as a black box, with incoming funding and outgoing funding channels and no internal structure. The internal workings of the country program are not considered, i.e. the incoming funding stream is not considered connected to a particular outgoing channel; thus incoming country program funding is treated in a similar way to a pooled fund.

This approach has two major benefits: firstly it massively simplifies data collection, as only aggregated country program-level data needs to be obtained and thereby ensures scalability. Secondly, the focus on the country program level which summarizes all individual project flows ensures that cross-subsidization from one project activity to another within one organization and country program will not distort the data set.

Cross-subsidization is common when studying funding flows on a project level. In DI's traceability studies as well as in CERF's HC/RC reports, there are examples of projects by some UN agencies or INGOs for which 100 percent of the received funding is reported to be channeled to the local/national humanitarian actor. Such efficient use of funding seems only plausible if other resources from other funding sources within the country program of the organization are used to cover, for example, the organizations' costs related to working with an implementing partner. By looking at country-level flows, these non-representative flows (100 percent of the received funding passed on to national actor) are assumed to be averaged out. 


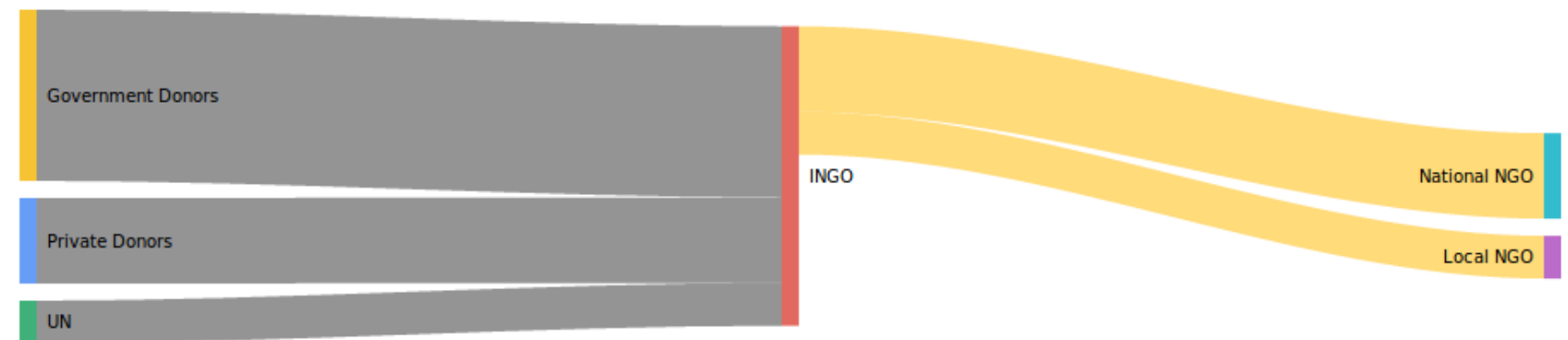

(c) Author (Christian Els), 2017.

Figure 2 illustrates incoming funding flows from UN, private donors and government grants for an INGO (gray) and subsequent outgoing funding flows to national and local NGOs (yellow). The information on incoming/outgoing flows for an entire country program of an INGO/RCRC/UN agency is the primary building block of data for this study.

\section{Data analysis: key figures}

Based on the collected data from UN, donors, INGOs and national and local NGOs, a set of key figures can be calculated:

a. Total surveyed direct funding from international government and private donors to LNHA per organization type and grand total to all LNHA

Method: aggregate funding flows to ONS, LNGO, NNGO from surveyed international donors funding local and national government, based on OECD CRS data and amended by data provide by international government donors

b. Total surveyed funding channeled to LNHA per organization type and grand total for all LNHA

Method: aggregated funding flows to ONS, LNGO, NNGO and local and national government from surveyed INGOs, UN, ICRC, PNS, IFRC and international donors. Direct private funding flows to L/NNGOs and ONS as well as funding from local and national government should not be included in this figure. These direct private funding flows can, if available, be presented in a separate category.

c. Total surveyed international humanitarian response

The total surveyed international humanitarian response on a country level includes the total aggregate of the received funding from all surveyed UN agencies, INGOs, IFRC, ICRC, PNS and international government grants to L/NNGO, ONS and affected government. In order to avoid double counting, funding from UN $\rightarrow$ INGO, UN $\rightarrow$ PNS, INGO $\rightarrow$ INGO, UN $\rightarrow$ ICRC/IFRC has to be subtracted.

The total surveyed international humanitarian response can be compared with the total reported funding of OCHA FTS and OECD CRS and should be at least 50 percent of the reported FTS funding to ensure that presented data is somewhat representative.

Since UN agencies and INGOs do not usually use their entire funding received in any given year but carry over funding to ensure liquidity, the total, aggregated carry-overs should be calculated as well.

\section{d. LNHA funding percentage}

The total surveyed funding channeled to LNHA can be compared with the total surveyed international humanitarian response to calculate the percentage of total funding that was given the LNHA. 


\section{e. LNHA funding per organization}

Based on data provided by aid organizations or donors, the percentage of the total funding that was channeled to the LNHA can be calculated per organization.

Depending on the availability and depth of data, more key figures might be calculated.

\section{Data analysis: direct and indirect funding flows}

\section{Pro rata assumption}

Since funding flows are not investigated on a project level, UN and INGOs' LNHAs funding cannot be ascribed to a particular donor. Instead, it is assumed that the relevant donor's share is proportional to the size of the donor if no other information is available.

For example if a UN agency receives total funding of $\$ 10 \mathrm{~m}$ (80 percent from governments and 20 percent from private donors) and consequently sub-grants $\$ 1 \mathrm{~m}$ to a national $\mathrm{NGO}$, it is assumed that sub-granting is done on a pro-rata basis, i.e. $\$ 800,000$ of the sub-grant originates from government funding and $\$ 200,000$ from private funding.

UN agencies, INGOs and RCRC organizations will be given the chance to comment on this assumption and can provide more detailed data on the origin of the funding that is sub-granted to an LNHA. If no such data is provided, the data analysis will be based on this pro-rata assumption.

\section{Figure 3: Sub-grants are ascribed to donors according to their relative size}

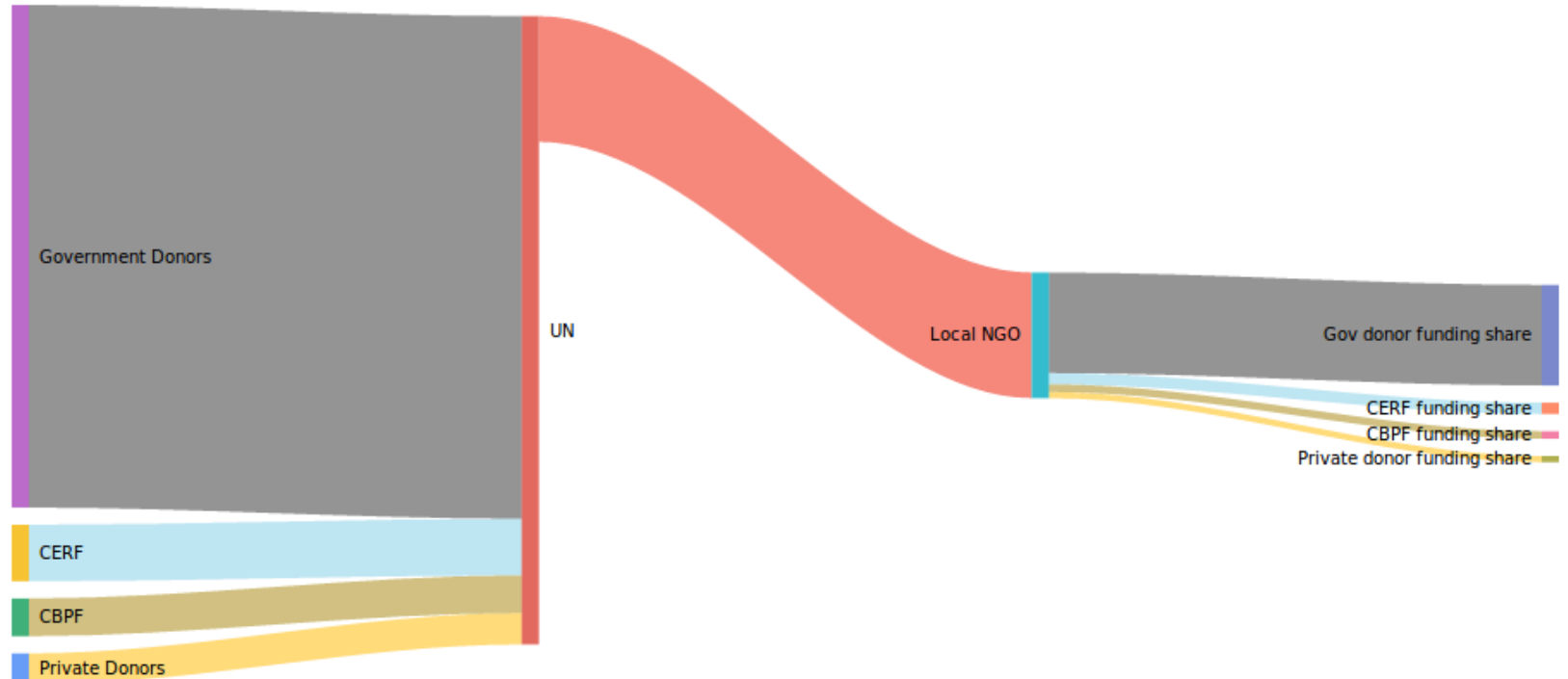

(c) Author (Christian Els), 2017.

Figure 3 shows incoming funding to a UN agency which provides a sub-grant to a local NGO. If no other information is available, the origin of the sub-grant funding will be ascribed pro-rata to the donors of the UN agency.

Based on this assumption, there are three types of flows: direct funding flows, and flows with one and two intermediaries (see Table 2). 
Table 2: Types of funding flow

\begin{tabular}{|c|c|c|}
\hline Direct flows & One intermediary & Two intermediaries \\
\hline $\begin{array}{l}\text { International donor } \\
\text { gov } \rightarrow \text { LNHA }\end{array}$ & $\begin{array}{l}\text { Possible UN/INGO } \\
\text { channels } \\
\text { International donor gov } \rightarrow \\
\text { UN } \rightarrow \text { LNHA } \\
\text { International donor gov } \rightarrow \\
\text { INGO } \rightarrow \text { LNHA } \\
\text { Private donors } \rightarrow \text { UN } \rightarrow \\
\text { LNHA } \\
\text { Private donors } \rightarrow \text { INGO } \\
\rightarrow \text { LNHA }\end{array}$ & $\begin{array}{l}\text { UN/INGO } \\
\text { International donor gov } \rightarrow \text { other } \\
\text { INGO } \rightarrow \text { INGO } \rightarrow \text { LNHA } \\
\text { International donor gov } \rightarrow \text { UN } \\
\rightarrow \text { INGO } \rightarrow \text { LNHA } \\
\text { Private donor } \rightarrow \text { other INGO } \rightarrow \\
\text { INGO } \rightarrow \text { LNHA } \\
\text { Private donors } \rightarrow \text { UN } \rightarrow \text { INGO } \\
\rightarrow \text { LNHA }\end{array}$ \\
\hline $\begin{array}{l}\text { Private donors } \rightarrow \\
\text { LNHA }\end{array}$ & $\begin{array}{l}\text { Pooled funds } \\
\text { International donor gov } \rightarrow \\
\text { CBPF } \rightarrow \text { LNHA }\end{array}$ & $\begin{array}{l}\text { Pooled funds } \\
\mathrm{CBPF} \rightarrow \mathrm{UN} \rightarrow \mathrm{LNHA} \\
\mathrm{CERF} \rightarrow \mathrm{UN} \rightarrow \mathrm{LNHA} \\
\mathrm{CBPF} \rightarrow \mathrm{INGO} \rightarrow \mathrm{LNHA}\end{array}$ \\
\hline
\end{tabular}

If there are instances of more than two intermediaries, this should be included in the analysis. There may be instances where a national NGO (which receives funding through the UN and INGOs) further implements with a local NGO; it is recommended to collect data and information on that.

Using data on donors and the size of outgoing funding flows, the 'directness' of a funding flow can be determined. Outgoing funding flows are ascribed to the various donors and data is analyzed on a country level for each organization.

Example: The total incoming funds for an INGO in 2015 amounted to $\$ 10 \mathrm{~m}$, of which 20 percent originates from the UN, 50 percent from government donors, 20 percent from private donors and 10 percent from other INGOs.

The INGO subsequently sub-grants $\$ 1 \mathrm{~m}$ to a national NGO. According to the approach discussed above $\$ 700,000$ ( $\$ 500,000$ from governments and $\$ 200,000$ from private donors) of this sub-grant is funding with one intermediary (the INGO itself) and $\$ 300,000$ ( $\$ 200,000$ from UN and $\$ 100,000$ from other INGOs) is funding with two intermediaries.

All the collected data on funding channeled through INGOs, UN and RCRC members will be analyzed as in the example provided and the relative sizes of direct and non-direct funding channels can be determined on a country level.

\section{B. How long is the transaction chain?}

For this research question, a small number of UN agencies and INGOs and their largest implementing partners (and if necessary sub-implementing partners) are approached. For a number of large projects, the number of intermediaries between UN/INGO and the people affected by crises is documented and the total original funding either from donor or UN agency. No data on actual financial flows will be captured (since this is too time consuming when done on a large scale); instead, the length of the transaction chain on the largest possible scale will be documented. Questions will be attempted on a country level, along the lines of: do UN sub-granted INGOs work with implementing partners? Do INGO sub-granted national NGOs further sub-grant to local NGOs?

This part of the research aims for results along the lines of: 25 percent of the reported OCHA FTS funding was implemented by the UN and INGOs without intermediary, 30 percent with one LNHA between UN/INGO and people affected by crises, and 10 percent with two intermediaries. 


\section{How is the workload divided between international and national actors?}

- Mapping of all LNHA and the number of staff members and volunteers

- Mapping of all UN agencies and INGOs and the number of staff members

- Based on the availability of data, security concerns, etc. Some regional or project focus might be necessary.

\section{LEVEL TWO}

While Level 1 data is mainly quantitative data, for Level 2 both qualitative and quantitative data will be used. For the qualitative aspects of the research, semi-structured interviews are suggested and an interview guide should be developed. This guide should include questions about earmarking, the nature of partnership, and best practice examples and barriers for more direct and better quality funding of LNHAs. It is also on this level that qualitative and quantitative data can be combined to present examples of best practice.

For this reason, LNHAs can simply be asked about specific projects for which the collaboration with international actors (donors, INGOs, UN, pooled funds) were particularly (un)successful and what contributed to the success or failure of the collaborations. One possible way of identifying such examples is to approach the topic from a business perspective and ask for examples of good and bad 'deals' that LNHAs were offered and agreed on with donors, INGOs and UN agencies.

Previous research in the context of the Syria response ${ }^{5}$ indicates that this way of approaching partnership resonates well with many local LNHAs. While existing analysis of the collaboration between national and international actors distinguishes between 'subcontracting' and 'partnership', 6 there is no single set of criteria which would help to delineated one form the other, and the business perspective is a simple way of unpacking the concept of partnership in very practical terms.

Some of the examples mentioned by LNHAs can then be used to illustrate and exemplify best practice policy recommendations. There might be examples of 'good deals' where LNHAs were involved in the very beginning in the design of the project; sufficient overhead costs were paid; the project entailed a large capacity building component; the level of earmarked funding was low, etc. The selection of such best practice examples should provide solutions to some of the countryspecific or global challenges of increasing funding flows to LNHAs.

Financial aspects are likely to play an important role in the best practice examples, and one way of illustrating this can be by tracing funding for a particular project from donor (through international actor) to L/NHA with a detailed breakdown of all cost components, including costs for overheads, capacity building, etc., in a similar way to existing traceability studies. ${ }^{7}$

Tables 3 and 4 offer examples of questions asked in Bangladesh. Not all of the questions will be relevant or useful in all contexts, and these questions should be adapted with local actors and based on local knowledge. 
Table 3: Qualitative questions for adaptation on existing humanitarian funding mechanisms

\begin{tabular}{|c|c|}
\hline Question for fund provider & Question for fund receiver (LNHA) \\
\hline $\begin{array}{l}\text { 1. What is the process you follow to select } \\
\text { a local/national partner? }\end{array}$ & $\begin{array}{l}\text { 1. What are the requirements you have to satisfy to } \\
\text { be a partner of an international fund provider? }\end{array}$ \\
\hline $\begin{array}{l}\text { 2. How do you conduct pre-award } \\
\text { assessments of your L/N partner? }\end{array}$ & $\begin{array}{l}\text { 2. What are the stages you have to pass to get } \\
\text { foreign funding? }\end{array}$ \\
\hline $\begin{array}{l}\text { 3. What are the statutory requirements in } \\
\text { Bangladesh to provide funding in the } \\
\text { humanitarian sector? }\end{array}$ & $\begin{array}{l}\text { 3. What are the statutory requirements in } \\
\text { Bangladesh to provide funding in the humanitarian } \\
\text { sector? }\end{array}$ \\
\hline $\begin{array}{l}\text { 4. What are the statutory requirements in } \\
\text { Bangladesh to provide funding to local } \\
\text { and national actors? }\end{array}$ & $\begin{array}{l}\text { 4. What are the statutory requirements in } \\
\text { Bangladesh to provide funding to local and national } \\
\text { actors? }\end{array}$ \\
\hline $\begin{array}{l}\text { 5. What reporting mechanisms exist } \\
\text { between you and your local/national } \\
\text { partners? }\end{array}$ & $\begin{array}{l}\text { 5. What are the reporting mechanisms that exist } \\
\text { between you and your international partners? }\end{array}$ \\
\hline $\begin{array}{l}\text { 6. How many local and national partners } \\
\text { did you have in } 2015 \text { for your } \\
\text { humanitarian response work? }\end{array}$ & $\begin{array}{l}\text { 6. How many foreign donors did you have in } 2016 \\
\text { for your humanitarian response work? }\end{array}$ \\
\hline $\begin{array}{l}\text { 7. In what form do you prefer to transfer } \\
\text { assets to your national partners (goods, } \\
\text { services, and/or cash) and why? }\end{array}$ & $\begin{array}{l}\text { 7. In what form do you prefer to receive assets from } \\
\text { your international partners (goods, services, and/or } \\
\text { cash) and why? }\end{array}$ \\
\hline $\begin{array}{l}\text { 8. What are the challenges you face while } \\
\text { working with and transferring funds to } \\
\text { LNHAs? }\end{array}$ & $\begin{array}{l}\text { 8. What form of support (goods, services, and/or } \\
\text { cash) do you think beneficiaries ultimately find most } \\
\text { beneficial, and why? }\end{array}$ \\
\hline $\begin{array}{l}\text { 9. How many intermediaries are involved } \\
\text { before goods, services, and cash reach } \\
\text { people participating in your response } \\
\text { programmes (i.e. beneficiaries)? }\end{array}$ & $\begin{array}{l}\text { 9. What are the differences in funding modalities to } \\
\text { you between an international partner and a national } \\
\text { partner? }\end{array}$ \\
\hline $\begin{array}{l}\text { 10. What are the differences in funding } \\
\text { modalities/mechanisms between you and } \\
\text { another international organization, and } \\
\text { that with a local or national partner? }\end{array}$ & $\begin{array}{l}\text { 10. What are the challenges you face while working } \\
\text { with and receiving funds from international actors } \\
\text { (donors, UN, INGOs)? }\end{array}$ \\
\hline $\begin{array}{l}\text { 11. What are the measures you think } \\
\text { would minimize the constraints in that } \\
\text { funding modality/mechanism? }\end{array}$ & $\begin{array}{l}\text { 11. What are the measures you think would } \\
\text { minimize the constraints in that funding } \\
\text { modality/mechanism? }\end{array}$ \\
\hline
\end{tabular}

Table 4: Sample qualitative questions for adaptation on partnership patterns, including concepts of trust, obligation, and program implementation responsibilities

\section{Question for fund provider}

1. At what stage of a project do you involve partners?

2. How do you specify the responsibilities between you and national/local partners?

3. Have you ever undertaken capacity development work with your national/local partner? If yes, can you provide details, including in how you document this work?

4. What other measures do you take to support the strength and independence of a national/local partner?
Question for fund receiver (LNHA)

1. At what stage of a project do you begin working with your international partners?

2. How do you agree on the responsibilities between you and international partners?

3. How are budgets developed when you enter into an agreement with an international funder? Or: How are costs for projects agreed between you and your international partner, including overheads, staffing, and other project costs?

4. How are decisions made on the type of intervention your program will deliver? (Programs partnered with/funded by an international 


\begin{tabular}{|c|c|}
\hline & organization) \\
\hline $\begin{array}{l}\text { 5. What are the challenges in the } \\
\text { relationship between local, national, and } \\
\text { international partners? }\end{array}$ & 5. Are changes in budgets well communicated? \\
\hline \multirow[t]{7}{*}{$\begin{array}{l}\text { 6. How can those challenges be } \\
\text { minimized? }\end{array}$} & $\begin{array}{l}\text { 6. How do international partners monitor your work } \\
\text { and communicate with you on compliance issues? }\end{array}$ \\
\hline & $\begin{array}{l}\text { 7. What is the reporting mechanism between you } \\
\text { and your international partner/donor? }\end{array}$ \\
\hline & $\begin{array}{l}\text { 8. Do you feel your relationship is well balanced? If } \\
\text { not, what would be necessary for the relationship to } \\
\text { become better balanced? }\end{array}$ \\
\hline & $\begin{array}{l}\text { 9. What are the challenges in your relationship with } \\
\text { your international partner/donor? }\end{array}$ \\
\hline & 10. How can those challenges be minimized? \\
\hline & $\begin{array}{l}\text { 11. Have you ever participated in capacity building } \\
\text { activities organized by your international partner? } \\
\text { Please provide details. }\end{array}$ \\
\hline & $\begin{array}{l}\text { 12. What kind of capacity development would your } \\
\text { organization want most? }\end{array}$ \\
\hline
\end{tabular}




\section{LEVEL THREE}

\section{How much funding reaches people affected by crises?}

Research for this section tries to answer the question: how much donor (private and governmental) money is needed to deliver $\$ 1$ worth of food/relief items? This will be done by tracking funding backwards from a LNHA through UN/INGO to donors and by considering costs on all levels, directly or indirectly related to the delivery of the food/relief items, most of which are include in Figure 4. The feasibility of this research depends heavily on the willingness of UN agencies and INGOs to share data. The main idea is to not only include direct cost components such as the costs for the relief items, transport costs and sub-grants to the LNHA, but also all indirect costs of the international actors. ${ }^{8}$ Indirect costs such as country office costs, HQ costs, etc., will be considered on a pro-rata basis based on the size of the project. In addition, pro-rata shares of costs for services by OCHA, and WFP's special operations related to logistics and ICT are considered, which usually are provided for the entire humanitarian community in a given country.

While the relevant shares of UN/INGOs HQ expenses can be estimated fairly easy from publicly available annual reports, a detailed breakdown of UN/INGOs overall in-country expenditure is needed, so that all relevant indirect cost components can be considered.

\section{Figure 4: Direct and indirect costs to deliver relief to people affected by emergencies}

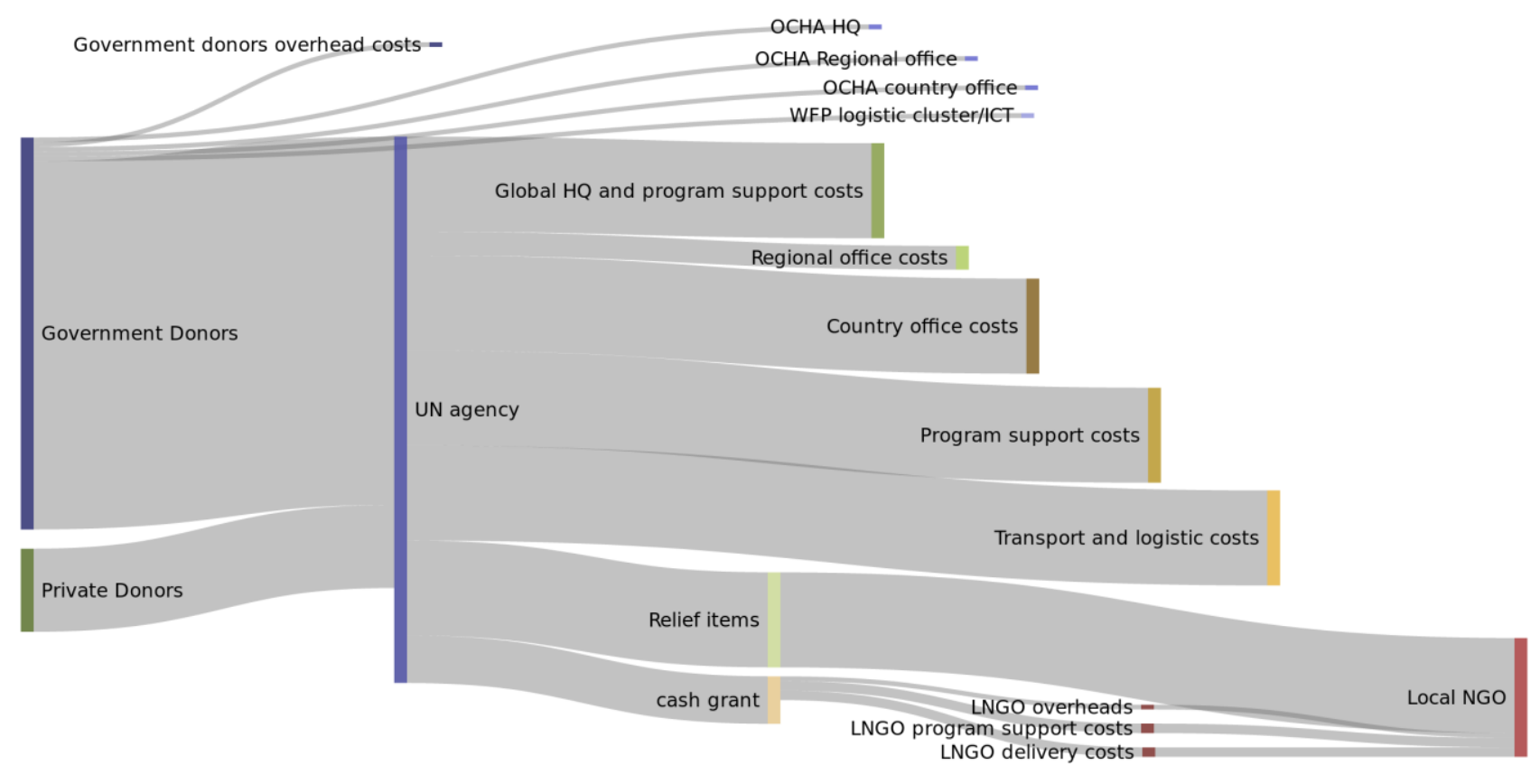

(c) Author (Christian Els), 2017. 


\section{Annex 1: Templates for Level 1 data collection}

Name of organization

January-December 2015
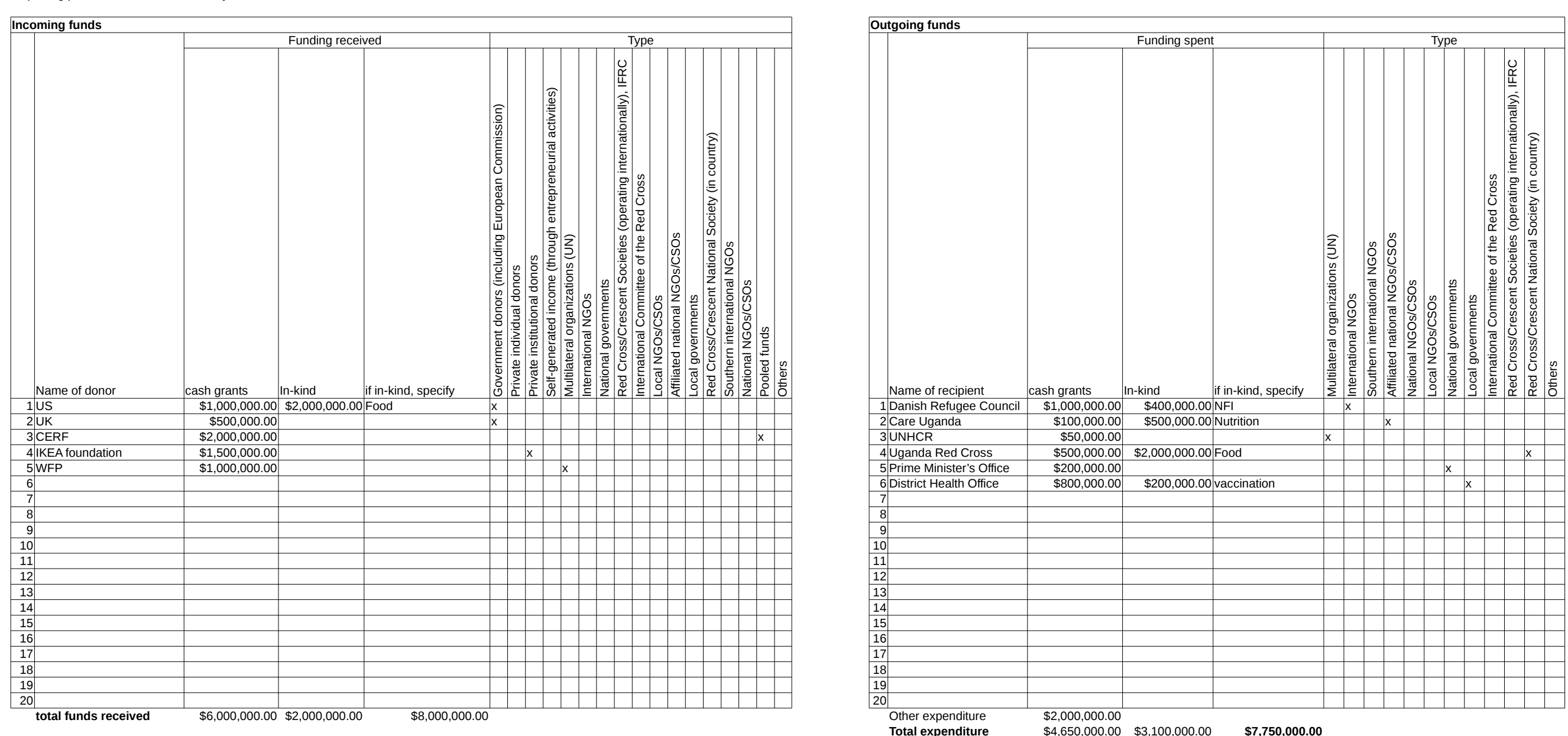

Definitions

National NGOs/CSOs: NGOs/CSOs operating in the aid recipient country in which they are headquartered, working in multiple subnational regions, and not affiliated to an international NGO.

Local NGOS/CSOS: NGOS/CSOs operating - either formally/registered or informally/unregistered - in a specific, geographically defined, subnational area of an aid recipient country, without affiliation to either a national or international NGO/CSO

This grouping can also include community-based organizations and faith-based organizations.

Southern international NGOs: NGOs not based in aid recipient countries, carrying out operations in one or more aid recipient countries and not affiliated to international NGOs or branches of an international NGO.

International NGOs: NGOs not based in an aid recipient country and carrying out operations in one or more aid recipient countries.

Red Cross/Red Crescent National Society: National Society that is based in aid recipient countries.

. National governments. National authontes in aid recipient countres eg.National Disast Management Agencies (NDMAs).

(O)

Societies that operate outside their home country (German Red Cross working in South Sudan, and International Federation of Red Cross and Red Crescent Societies (IFRC)

Other expenditure: all expenditures that were not channeled to partners 
1 The Grand Bargain - a Shared Commitment to Better Serve People in Need. Signed following the World Humanitarian Summit, May 2016. See http://www.agendaforhumanity.org/initiatives/3861

2 Including the Charter4Change, July 2015. See http://reliefweb.int/sites/reliefweb.int/files/resources/Charter\%20for\%20Change\%20\%20July\%202015.pdf

3 T. Mowjee, L. Poole and B. Willitts-King (2017). From Grand Bargain to Beneficiary: An analysis of funding flows through the humanitarian system. Overseas Development Institute (ODI). https://www.odi.org/publications/10823-grand-bargain-beneficiary-analysis-funding-flows-throughhumanitarian-system

4 Development Initatives (2015). Global Humanitarian Assistance Report 2015. p126-7.

5 Christian Els, Kholoud Mansour and Nils Carstensen. May 2016. Funding to national and local humanitarian actors in Syria. Local to Global Protection.

6 Kimberly Howe, Elizabeth Stites, and Danya Chudacoff. (2015). Breaking the Hourglass: Partnership in Remote Management Settings - The Cases of Syria and Iraqi Kurdistan. Tufts University, Feinstein International Center.

7 For example, Chloe Parrish. (2016). Better Information for a Better Response. p10. Development Initiatives, May 2016.

8 For an outline of the main idea, see also: Els at al. (2016). Op. cit.

Oxfam research reports are written to share research results and methodologies, to contribute to public debate and to invite feedback on development and humanitarian policy and practice. They do not necessarily reflect Oxfam policy positions. The views expressed are those of the author and not necessarily those of Oxfam.

This report was written by Christian Els. Oxfam acknowledges the contributions of Chloe Parrish of Development Initiatives, and Sabuj Dobey of Dobey International to this methodology.

For more information, or to comment on this report, email Anita.Kattakuzhy@oxfamnovib.nl

(C) Oxfam International August 2017

This publication is copyright but the text may be used free of charge for the purposes of advocacy, campaigning, education, and research, provided that the source is acknowledged in full. The copyright holder requests that all such use be registered with them for impact assessment purposes. For copying in any other circumstances, or for re-use in other publications, or for translation or adaptation, permission must be secured and a fee may be charged. Email policyandpractice@oxfam.org.uk

The information in this publication is correct at the time of going to press.

Published by Oxfam GB for Oxfam International under ISBN 978-1-78748-031-5 in August 2017.

DOI: $10.21201 / 2017.0315$

Oxfam GB, Oxfam House, John Smith Drive, Cowley, Oxford, OX4 2JY, UK.

\section{OXFAM}

Oxfam is an international confederation of 20 organizations networked together in more than 90 countries, as part of a global movement for change, to build a future free from the injustice of poverty. Please write to any of the agencies for further information, or visit www.oxfam.org 